\author{
N.V. Danyliuk, T.R. Tatarchuk, A.V. Shyichuk
}

\title{
Batch Microreactor for Photocatalytic Reactions Monitoring
}

\author{
Vasyl Stefanyk Precarpathian National University, Ivano-Frankivsk, Ukraine, danyliuk.nazariy@gmail.com
}

\begin{abstract}
Photocatalytic oxidation of organic contaminants is a hot topic in environmental research. However, an effective purification process needs an effective photoreactor. Typical light sources such as mercury and halogen lamps are replaced with more energy efficient Light Emitting Diodes. In the current work, a miniature photoreactor with low catalyst consumption was presented. The work of the micro-photoreactor is investigated using anatase and P25 industrial titania as model catalysts. The key element of the microreactor is replaceable UV-LED. The used $365 \mathrm{~nm}$ emission wavelength is optimal for the model pollutant Rhodamine B dye. The micro-photoreactor is able almost completely to mineralize the Rhodamine B dye.
\end{abstract}

Key words: micro-photoreactor, rhodamine B, photocatalyst, LED, photodegradation.

Received 06 May 2020; Accepted 15 June 2020.

\section{Introduction}

In the last years, much attention is paid to "green" methods of wastewater remediation [1-4]. Photocatalysis is considered as a promising method of organic pollutant degradation. Photocatalytic oxidation leads to complete degradation of organic pollutants. The final products are non-toxic substances $\mathrm{CO}_{2}$ and $\mathrm{H}_{2} \mathrm{O}$. Sunlight-activated photocatalyst leads to splitting of water molecules and formation of hydroxyl radicals. The highly aggressive radicals destroy the pollutant molecules [5-7]. It is known that the most active photocatalysts are $\mathrm{TiO}_{2}[8$ 10] and $\mathrm{ZnO}[11,12]$. Both the substances are inexpensive, non-toxic and chemically stable. However, the drawback is that these oxides absorb ultraviolet photons only. The UV part of the Sun energy is known to be $5 \%$ only. For that reason, the key characteristics of photocatalyst is energy band gap, related strongly with crystalline structure. For example, the band gap for anatase, rutile, and brookite polymorphs of $\mathrm{TiO}_{2}$ are 3.23 $\mathrm{eV}, 3.1 \mathrm{eV}$ and $3.4 \mathrm{eV}$, respectively [13]. This is due to the difference in crystal lattice parameters and spatial locations of $\mathrm{TiO}_{6}$ octahedra, in which $\mathrm{Ti}^{4+}$ ions are coupled with six $\mathrm{O}^{2-}$ ions. The anatase and rutile have tetragonal structure with different spatial arrangement of $\mathrm{TiO}_{6}$ octahedra (Fig. 1) [13]. The crystal lattice distances are: $\mathrm{a}=\mathrm{b}=3.78 \AA, \mathrm{c}=9.50 \AA$ for anatase and $\mathrm{a}=\mathrm{b}=4.58 \AA, \mathrm{c}=2.95 \AA$ for rutile. Instead, brookite polymorph has an orthorhombic crystalline structure with lattice parameters $\mathrm{a}=5.43 \AA, \mathrm{b}=9.16 \AA$, and $\mathrm{c}=5.13 \AA$ [13]. The differences in crystalline structure cause different photocatalytic activities of the three titania polymorphs. The most active is rutile [14]. This is why extensive research are focused on simple and environment friendly methods of rutile production [1519].

Titania photocatalytic activity may be improved via doping with heavy elements such as $\mathrm{Fe}, \mathrm{Co}, \mathrm{Ga}, \mathrm{W}, \mathrm{Bi}$, $\mathrm{Mo}, \mathrm{V}$ and $\mathrm{Ni}$ [20]. The dopants reduce rate of electronholes recombination and extend the photocatalyst lifetime. Dopant amount should be chosen correctly. Too high modifier amount may distort crystal lattice and reduce photocatalytic activity. Optimal dopant amount is below $3 \%$ [20]. On the other hand, heavy metal dopants are hazardous pollutants. Thus gradual photocatalyst destruction can lead to heavy metal dissemination. Surface properties of titania may be modified via grafting phosphate [21], arsenate [22], and carbonate [23] groups.

An important step in developing water purification method is optimization of experimental conditions. The photocatalyst efficiency is usually evaluated measuring rate of model pollutant decomposition. Common model pollutants are organic dyes [24-29]. Among them the Rhodamine $\mathrm{B}$ dye $(\mathrm{RhB})$ is very sensitive to hydroxyl radicals $[6,7,30-32]$. The $\mathrm{RhB}$ dye is photooxidized to colorless products, so its decomposition rate may be 


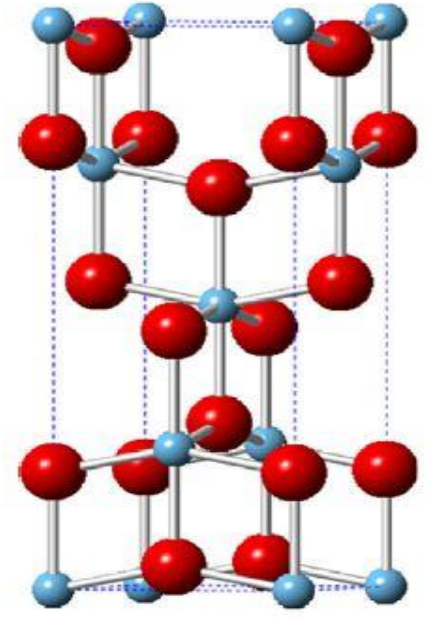

Anatase

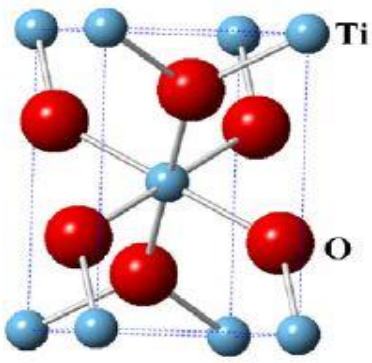

Rutile

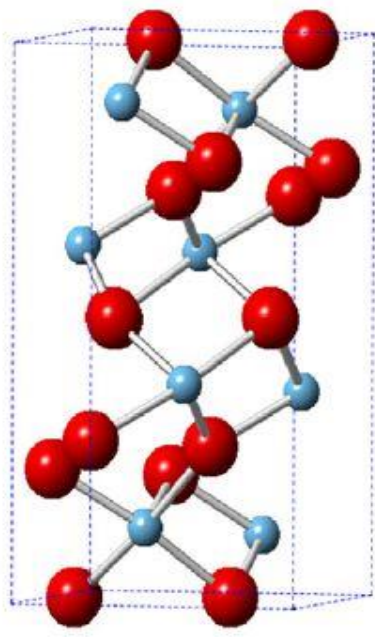

Brookite

Fig. 1. Crystal structure of anatase, rutile and brookite [10].

easily monitored by photometry. The main factors affecting the rate and degree of $\mathrm{RhB}$ photodegradation are UV radiation power and photocatalyst activity. Oxygen vacancies on titania surface are active centers for superoxide radical formation. Superoxide and hydroxyl radicals are highly reactive to degrade organic pollutants. For example, Zhang and others [32] completely discolored $\mathrm{RhB}$ solution $\left(10^{-5} \mathrm{M}\right)$ for $120 \mathrm{~min}$ under $20 \mathrm{~W}$ UV irradiation using $\mathrm{Fe}-\mathrm{CNT} / \mathrm{TiO}_{2}$ catalyst. Guo et al. [6] described effect of $\mathrm{H}_{2} \mathrm{O}_{2}$ on $\mathrm{RhB}$ decomposition. Addition of $\mathrm{H}_{2} \mathrm{O}_{2}$ results in formation of large amount of hydroxyl radicals that destroy $\mathrm{RhB}$ molecules. However, excess of $\mathrm{H}_{2} \mathrm{O}_{2}$ may act as electron capture agent and cause recombination of electron-hole pairs. Phutanon et al. [5] used copper oxide for photocatalytic degradation of the $\mathrm{RhB}$ dye. Active centers in formation of superoxide radicals are oxygen vacancies in $\mathrm{CuO}$ structure.

Table 1

Features of laboratory photocatalytic reactors

\begin{tabular}{|c|c|c|c|c|}
\hline Reactor and solution volume & Model pollutant & Light source & Catalyst & Ref. \\
\hline Photoreactor, $250 \mathrm{ml}$ & textile dyes & $\begin{array}{c}\text { UV-LED } 11 \mathrm{~mW}, 200 \\
\mathrm{~mW} \\
\left(\lambda_{\max }=385 \mathrm{~nm}\right)\end{array}$ & $\mathrm{TiO}_{2}$ & [35] \\
\hline LED photoreactor, $1.5 \mathrm{~L}$ & {$\left[\mathrm{Co}(\mathrm{CN})_{6}\right]^{3-}$} & $\begin{array}{l}\text { UV-LED } 30 \mathrm{~W} \\
\left(\lambda_{\max }=365 \mathrm{~nm}\right)\end{array}$ & $\begin{array}{l}\mathrm{TiO}_{2}(\mathrm{P} 25, \\
\text { Aeroxide })\end{array}$ & [41] \\
\hline $\begin{array}{l}\text { Multistage rotating mesh } \\
\text { support photoreactor }\end{array}$ & p-nitrophenol & $\begin{array}{l}11 \mathrm{~W} \text { UV-C lamps } \\
\left(\lambda_{\max }=253.7 \mathrm{~nm}\right)\end{array}$ & $\mathrm{TiO}_{2} \mathrm{P}-25$ & [42] \\
\hline Batch photocatalytic reactor & phenol & $\begin{array}{l}\text { LED }(20 \mathrm{~mA}-25 \mathrm{~mA}) \\
\quad\left(\lambda_{\max }=375 \mathrm{~nm}\right)\end{array}$ & Degussa P-25 & [43] \\
\hline Mini-photoreactor, $23 \mathrm{ml}$ & n-decane & $\begin{array}{l}9 \text { UVA LEDs } 270 \mathrm{~mW} \\
\left(\lambda_{\max }=365 \mathrm{~nm}\right)\end{array}$ & $\mathrm{TiO}_{2}-\mathrm{P} 25$ & [44] \\
\hline Batch monolith photoreactor & $\begin{array}{c}\mathrm{CO}_{2} \text { reduction with } \\
\mathrm{H}_{2}\end{array}$ & $\begin{array}{c}200 \mathrm{~W} \mathrm{Hg} \\
\left(\lambda_{\max }=252 \mathrm{~nm}\right)\end{array}$ & $\begin{array}{c}\mathrm{TiO}_{2} \text { monolithic } \\
\text { catalyst }\end{array}$ & [45] \\
\hline $\begin{array}{l}\text { Photo-microfluidic chip reactor, } \\
0.0095 \mathrm{ml}\end{array}$ & propene oxidation & $\begin{array}{l}\text { UV-LED light } \\
\left(0.55 \mathrm{~W} / \mathrm{cm}^{2}\right)\end{array}$ & $\mathrm{TiO}_{2}$ & [36] \\
\hline $\begin{array}{l}\text { UV-LEDs floating-bed } \\
\text { photoreactor, } 200 \mathrm{ml}\end{array}$ & caffeine, paracetamol & $\begin{array}{l}\text { LED } 14 \mathrm{~W}^{*} \mathrm{~m}^{-1} \\
\left(\lambda_{\max }=365 \mathrm{~nm}\right)\end{array}$ & $\mathrm{ZnO}$ - Polystyrene & {$[11]$} \\
\hline $\begin{array}{l}\text { Continuous photoreactor, } 1500 \\
\mathrm{ml}\end{array}$ & Direct Red 23 & LED $3.6 \mathrm{~W}$ & UV-LED/ $/ \mathrm{S}_{2} \mathrm{O}_{8}{ }^{2-}$ & {$[26]$} \\
\hline $\begin{array}{l}\text { Flat-panel photoreactor, } \\
3.4 \mathrm{~L}\end{array}$ & Methylene Blue & solar illumination & $\mathrm{TiO}_{2}$ & [37] \\
\hline Stream reactor, $600 \mathrm{ml}$ & phenol & $\begin{array}{c}5 \mathrm{~W} \mathrm{Hg} \text { lamp } \\
\left(\lambda_{\max }=253.7 \mathrm{~nm}\right)\end{array}$ & $\mathrm{TiO}_{2}$ film & {$[46]$} \\
\hline Flow-through reactor, $1.5 \mathrm{~L}$ & $\begin{array}{c}\text { phenol, Reactive } \\
\text { blue }\end{array}$ & $\begin{array}{c}15 \mathrm{~W} \mathrm{Hg} \text { lamp } \\
\left(\lambda_{\max }=355 \mathrm{~nm}\right)\end{array}$ & $\begin{array}{l}\text { fiber glass strips } \\
\text { coated with } \mathrm{TiO}_{2}\end{array}$ & [47] \\
\hline
\end{tabular}


Continuation of Table 1

\begin{tabular}{|c|c|c|c|c|}
\hline LED photoreactor & Reactive blue & 6 UV-LED $1 \mathrm{~W}$ & $\mathrm{ZnO}$ & {$[48]$} \\
\hline Flat-plate photoreactor, $250 \mathrm{ml}$ & urea & $\begin{array}{c}\text { S-VD LED 25-78 W } \\
\left(\lambda_{\max }=550 \mathrm{~nm}\right)\end{array}$ & $\begin{array}{c}\text { nitrogen-doped } \\
\mathrm{TiO}_{2} \\
\end{array}$ & [49] \\
\hline $\begin{array}{l}\text { Mini-photoreactor, } \\
3 \mathrm{ml}\end{array}$ & $\begin{array}{l}\text { salicylic acid, } \\
\text { methylene blue }\end{array}$ & $\begin{array}{c}\text { UV-LED 5W } \\
\left(\lambda_{\max }=370 \mathrm{~nm}\right)\end{array}$ & $\mathrm{ZnO}$ & [34] \\
\hline Micro-photoreactor, $30 \mathrm{ml}$ & $\mathrm{RhB}$ & $\begin{array}{c}\text { UV-LED 3W } \\
\left(\lambda_{\max }=365 \mathrm{~nm}\right)\end{array}$ & $\mathrm{TiO}_{2}-\mathrm{P} 25$ & $\begin{array}{c}\text { This } \\
\text { article }\end{array}$ \\
\hline
\end{tabular}

Photoreactor design is crucial in developing an effective purification process. Typical limitation is low lighting efficiency. Table 1 describes features of laboratory photocatalytic reactors. Mini- and microphotoreactors are very convenient to study photocatalyst performance [11, 33-39]. The microreactors have several advantages such as: (i) low amount of photocatalyst needed; (ii) high light permeability throughout the reactor; (iii) uniform light distribution in the reactor space [40].

The light source plays an important role in photocatalytic processes. The very promising light sources are power UV LEDs. LEDs are environment friendly and are superior to mercury and halogen lamps $[11,26,34,41,43,48,50]$. With using LEDs, photoreactors are miniaturized in line with the basic principles of green chemistry. To be energy efficient, LED light sources should be optimized in terms of both power and emission spectrum. In the work [33] a LEDdriven reactor with variable light intensity was presented. The surfactant sodium dodecylbenzenesulfonate (SDBS) was used as a model solution. The most effective removal (approximately $94 \%$ ) was observed with electric power consumption of $27.5 \mathrm{~mW} \cdot \mathrm{cm}^{-2}$. In terms of energy efficiency, the best result has been obtained with energy consumption of $3.22 \mathrm{~mW} \cdot \mathrm{cm}^{-2}$ and SDBS degradation of $90 \%$. Removal of SDBS was far less effective under mercury lamp illumination. With degradation of $\mathrm{RhB}$ dye, energy consumption was several times higher than that with using modernized LED reactor. These data suggest that mercury lamps should be replaced by LEDs. Bukman et al. [34] proposed a new approach to evaluation of photoreaction performance. UV LED was combined with a spectrophotometer cuvette in order to perform measurements in situ. Such approach allows to calculate accurately rate constants of the photoreactions studied. Working volume of the mini-reactor is as small as $3.0 \mathrm{ml}$.

In this study, new photocatalytic micro-photoreactor is presented. The mini-reactor has volume of $30 \mathrm{ml}$. The small working volume allows all the catalyst particles to receive necessary illumination. In the same time, this reactor volume is enough to take several aliquots for analysis. To prevent the change in the total catalyst mass, the precipitate after centrifugation was returned back to the reactor. The mini-reactor is environmentally friendly due to small amount of catalyst and reagents used.

\section{Experimental}

Mixed anatase-rutile titania P25 come from Degussa (Germany). Reagent-grade titanium dioxide (anatase $99.7 \%)$ and Rhodamine $\mathrm{B}$ dye $\left(\mathrm{C}_{28} \mathrm{H}_{31} \mathrm{ClN}_{2} \mathrm{O}_{3}\right)$ were obtained from Sigma (now Merck). Structural formula of the Rhodamine B dye is presented in Fig. 2.

Spectra in the range $350-700 \mathrm{~nm}$ were registered with spectrophotometer ULAB 102-UV using $5 \mathrm{~mm}$ quartz cuvettes. Calibration line was plotted using absorbance at $558 \mathrm{~nm}$ against $\mathrm{RhB}$ concentration in the range from 1 to $20 \mathrm{mg} / \mathrm{L}$. The calibration plot is quite straight line with determination coefficient $\mathrm{R}^{2}=0.999$ (Fig. 3-b).

Photodegradation experiments were carried out using $30 \mathrm{~mL}$ of $5 \mathrm{mg} / \mathrm{L}$ aqueous solution of the $\mathrm{RhB}$ dye and $30 \mathrm{mg}$ of titania photocatalyst. Before the experiment, the reaction solution was stirred for $30 \mathrm{~min}$ in order to<smiles>CCN(CC)c1ccc2c(-c3ccccc3C(=O)O)c3ccc(=[N+]([O-])CC)cc-3oc2c1</smiles>

Fig 2. Rhodamine B dye structure. 
(a)

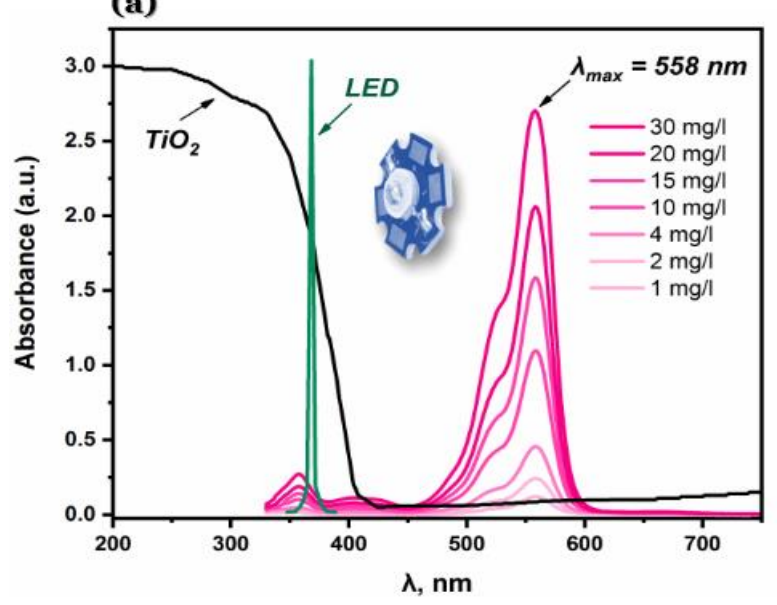

(b)

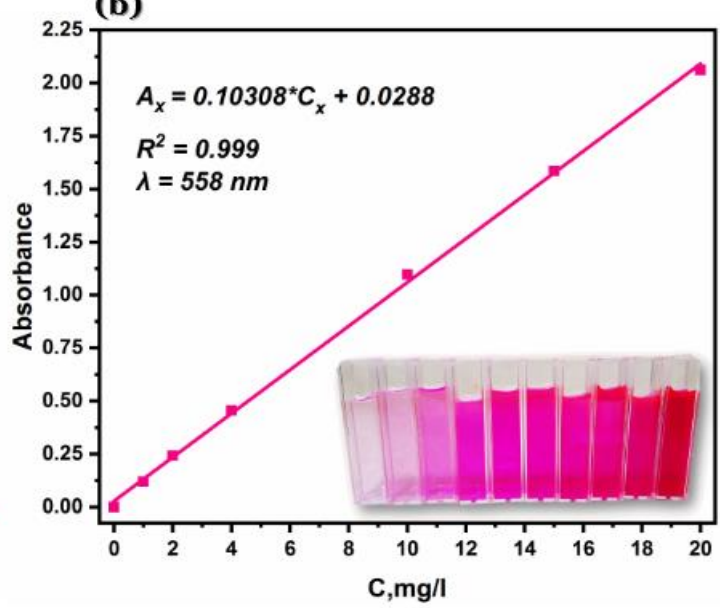

Fig. 3. (a) UV-vis spectrum of RhB solutions at indicated concentrations. (b) Absorbance at $558 \mathrm{~nm}$ (the spectral peak wavelength) versus RhB concentration.

equilibrate adsorption of the dye on titania surface. The solution $\mathrm{pH}$ was in the range from 6 to 7. Samples were collected at 0,180 , and 300 minutes. Fig. 4 shows images of $\mathrm{RhB}$ solution before and after photodegradation. The sample of $5 \mathrm{~mL}$ was centrifuged for 5 $\mathrm{min}$ at $3500 \mathrm{rpm}$. Supernatant was analyzed for the rest dye concentration while precipitate was returned back to the micro-reactor. Degradation extent was calculated as follows:

$$
K=\frac{A_{0}-A_{t}}{A_{0}} \times 100 \%,
$$

with $\mathrm{K}$ is degradation extent (\%), $\mathrm{A}_{0}$ is initial absorbance and $\mathrm{A}_{\mathrm{t}}$ is absorbance at time $\mathrm{t}$. (a)

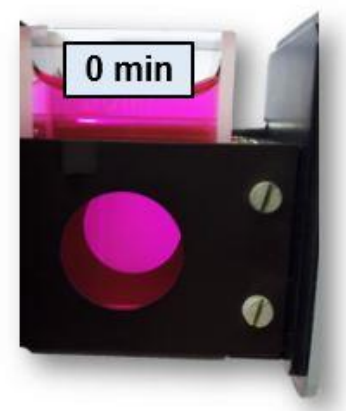

(b)

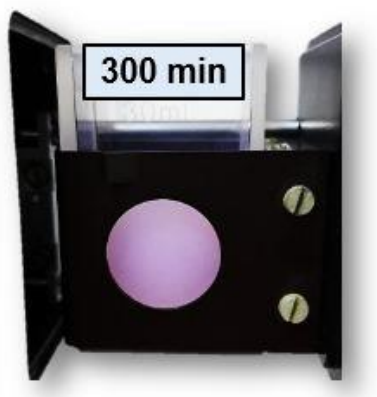

Fig. 4. Images of RhB solution before (a) and after (b) photo-degradation.

\section{Results}

\subsection{Design of the micro-photoreactor.}

Principal scheme of the micro-photoreactor is presented in Fig. 5. The main element is rectangle glass cuvette with $20 \mathrm{~mm}$ optical path. The cuvette volume is $30 \mathrm{~mL}$. Magnetic stirrer ensures even distribution of photocatalyst. The light source is a LED supplied with $700 \mathrm{~mA}$ current at $3.4-3.8 \mathrm{~V}$. The power LED is placed in a cooler designed to allow quick replacement. The cooler maintains temperature of the LED not exceeding $25^{\circ} \mathrm{C}$. General view of the cuvette housing is shown in
Fig. 6. The cuvette holder is moved to collect samples of the solution.

\subsection{Photocatalytic experiments.}

The microreactor was designed for rapid testing of photocatalysts. The exemplary study presents photocatalytic degradation of the RhB dye. The RhB dye is typical contaminant in textile and paper industrial waste waters [51-53]. The RhB dye is known to irritate skin, eyes and respiratory tract [54]. Due to strong absorbance, extent of the dye degradation can be easily monitored via spectrophotometric measurements. The dye molecule contains aromatic rings, sulfonate and amino groups typical for organic contaminants (Fig. 2). For that reason, the $\mathrm{RhB}$ dye is often used as model compound to study photocatalyst efficiency (Table 2).

Replaceable light source allows to choose wavelength optimal to absorbance spectrum of the substance studied. If the goal of a study is stability test of a substance, the wave length should match peak of the substance absorption spectrum. On contrary, a study on a catalyst efficiency requires minimal light absorption by a model substance. In the present study, wave length of the LED light source was $365 \mathrm{~nm}$. This wavelength corresponds to the range of minimal light absorption of the RhB dye (Fig. 3a). Thus, photodegradation of RhB dye is minimalized. On the other hand, the LED emission spectrum corresponds to the absorption range of the titania photocatalyst used (Fig. 3a). The $\mathrm{TiO}_{2}$ photocatalyst is usually activated with irradiation of short wavelengths less than $400 \mathrm{~nm}$. Optical power of the light source should be optimal for a studied catalyst [58]. In the present study, the luminous power was 15 lumen.

Efficiencies of the studied photocatalyts were evaluated using extent of the dye degradation. The numerical data are presented in Table 3. The data indicate clearly that the P25 catalyst has higher activity than anatase.

Spectra of the degraded RhB samples are presented in Fig. 7. There was no new spectral band registered. Decrease of the main absorption peak indicate degradation of the dye chromophore structure. In the case of the anatase catalyst, spectra of the samples are shifted 


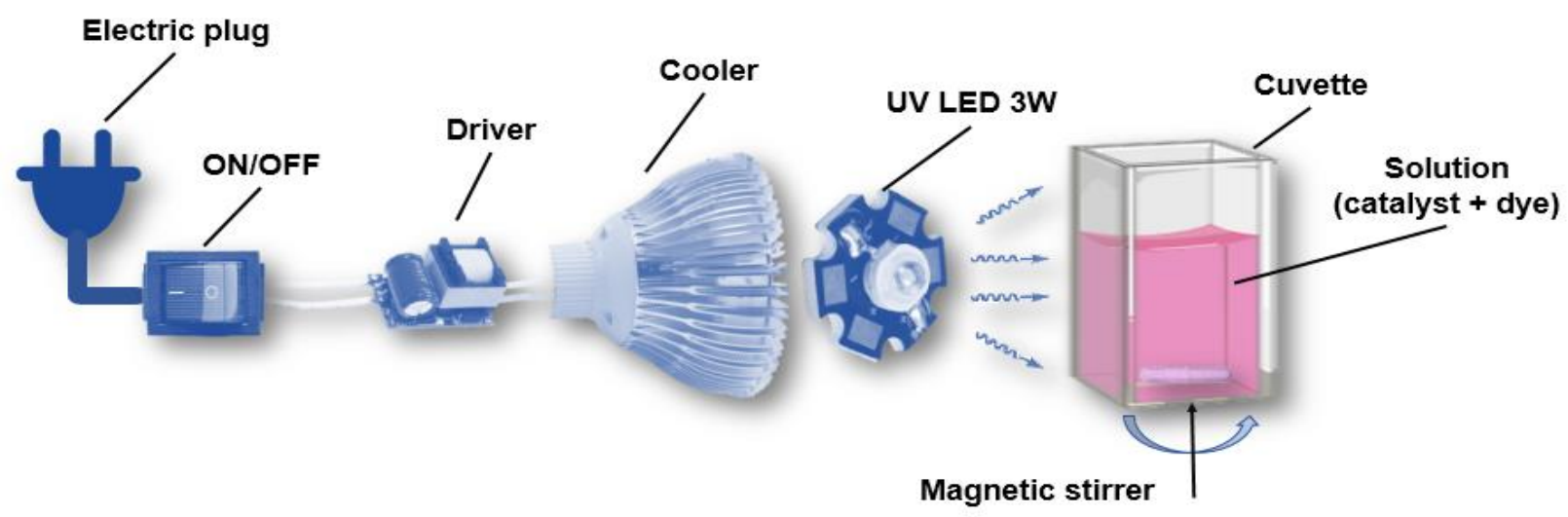

Fig. 5. Principal scheme of the micro-photoreactor.

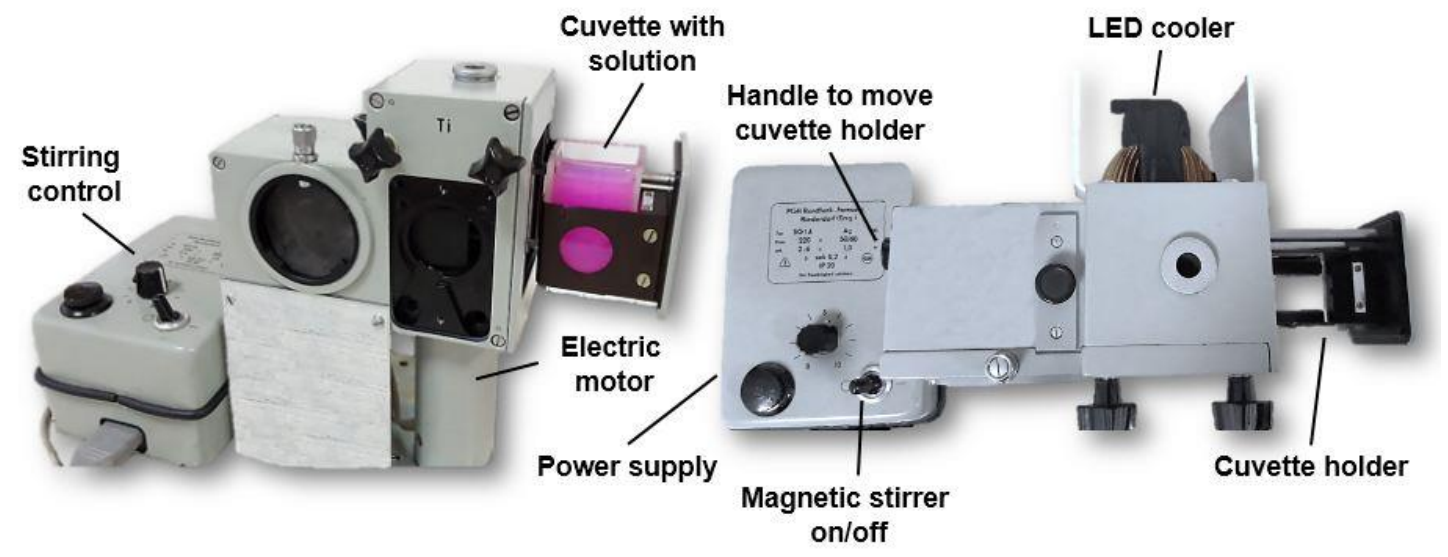

Fig. 6. General view of the micro-reactor for photocatalytic studies.

Table 2

The photocatalysts tested with using RhB dye

\begin{tabular}{|c|c|c|c|c|c|c|}
\hline Photocatalyst & Concentration & Dye concentration & Conditions & $\begin{array}{c}\text { Degradation } \\
\text { extent, } \%\end{array}$ & $\begin{array}{l}\text { Time, } \\
\text { min }\end{array}$ & Ref. \\
\hline $\mathrm{PVP} / \mathrm{AS} / 6 \% \mathrm{BiOBr}$ & $25 \mathrm{mg} / 50 \mathrm{~mL}$ & $10 \mathrm{mg} / \mathrm{L}$ & & 75 & 120 & [7] \\
\hline $\mathrm{Fe}_{3} \mathrm{O}_{4} \mathrm{NPs}$ & $4 \mathrm{~g} / \mathrm{L}$ & $0.025 \mathrm{mM}$ & $\begin{array}{l}30 \% \mathrm{H}_{2} \mathrm{O}_{2} \\
0.5 \mathrm{~mL} / \mathrm{L}\end{array}$ & 99.5 & 60 & [24] \\
\hline $\mathrm{Fe}_{2} \mathrm{O}_{3}+10 \% \mathrm{In}_{2} \mathrm{O}_{3}$ & $30 \mathrm{mg} / 100 \mathrm{~mL}$ & $100 \mathrm{mg} / \mathrm{L}$ & $\begin{array}{c}30 \% \mathrm{H}_{2} \mathrm{O}_{2} \\
50 \mu \mathrm{l} / 100 \mathrm{~mL} \\
\mathrm{pH}=4\end{array}$ & 94 & 20 & [6] \\
\hline $\mathrm{ZnO}$ & $\begin{array}{c}100 \mathrm{mg} / 100 \\
\mathrm{~mL}\end{array}$ & $50 \mathrm{mg} / \mathrm{L}$ & & 96 & 180 & [55] \\
\hline CR-ZnONPs & $20 \mathrm{mg} / 100 \mathrm{~mL}$ & $10 \mu \mathrm{M}$ & & 98 & 200 & [30] \\
\hline g- $\mathrm{C}_{3} \mathrm{~N}_{4} / \mathrm{TiO}_{2}(\mathrm{TC} 3)$ & $0.04 \mathrm{~g} / 30 \mathrm{~mL}$ & $10^{-5} \mathrm{M}$ & & 95.2 & 80 & {$[56]$} \\
\hline $\mathrm{Sn}_{0.05} \mathrm{Ti}_{0.95} \mathrm{O}_{2}-\mathrm{SBA}-15$ & $100 \mathrm{mg} / 100 \mathrm{~mL}$ & $50 \mu \mathrm{M}$ & $\mathrm{pH}=4.5$ & 99 & 180 & [57] \\
\hline $\mathrm{CuO}$ & $25 \mathrm{mg} / 100 \mathrm{~mL}$ & $1 \mathrm{ppm}$ & $\begin{array}{c}30 \% \mathrm{H}_{2} \mathrm{O}_{2} \\
0.1 \mathrm{~mL} / \\
100 \mathrm{~mL} \\
\end{array}$ & $*$ & 240 & [5] \\
\hline $\mathrm{KNbO}_{3}$ & $0.5 \mathrm{~g} / 200 \mathrm{~mL}$ & $10 \mathrm{mg} / \mathrm{L}$ & & - & 180 & [31] \\
\hline $\mathrm{Fe}-\mathrm{CNTs} / \mathrm{TiO}_{2}$ & $50 \mathrm{mg} / 50 \mathrm{~mL}$ & $10^{-5} \mathrm{M}$ & & 100 & 120 & {$[32]$} \\
\hline $\mathrm{TiO}_{2} \mathrm{P} 25$ (Degussa) & $30 \mathrm{mg} / 30 \mathrm{~mL}$ & $5 \mathrm{mg} / \mathrm{L}$ & & 97.3 & 300 & $\begin{array}{l}\text { this } \\
\text { article }\end{array}$ \\
\hline anatase $(99.7 \%)$ & $30 \mathrm{mg} / 30 \mathrm{~mL}$ & $5 \mathrm{mg} / \mathrm{L}$ & & 59.6 & 300 & $\begin{array}{l}\text { this } \\
\text { article }\end{array}$ \\
\hline
\end{tabular}

* rate constant $=0.002-0.007 \mathrm{~min}^{-1}$ 
Table 3

Extent of RhB dye degradation using P25 and anatase photocatalysts

\begin{tabular}{|l|c|c|}
\hline \multirow{2}{*}{ Catalyst } & \multicolumn{2}{|c|}{ Degradation (\%) } \\
\cline { 2 - 3 } & $180 \mathrm{~min}$ & $300 \mathrm{~min}$ \\
\hline P25 & 67.5 & 97.3 \\
\hline anatase & 39.7 & 59.6 \\
\hline
\end{tabular}
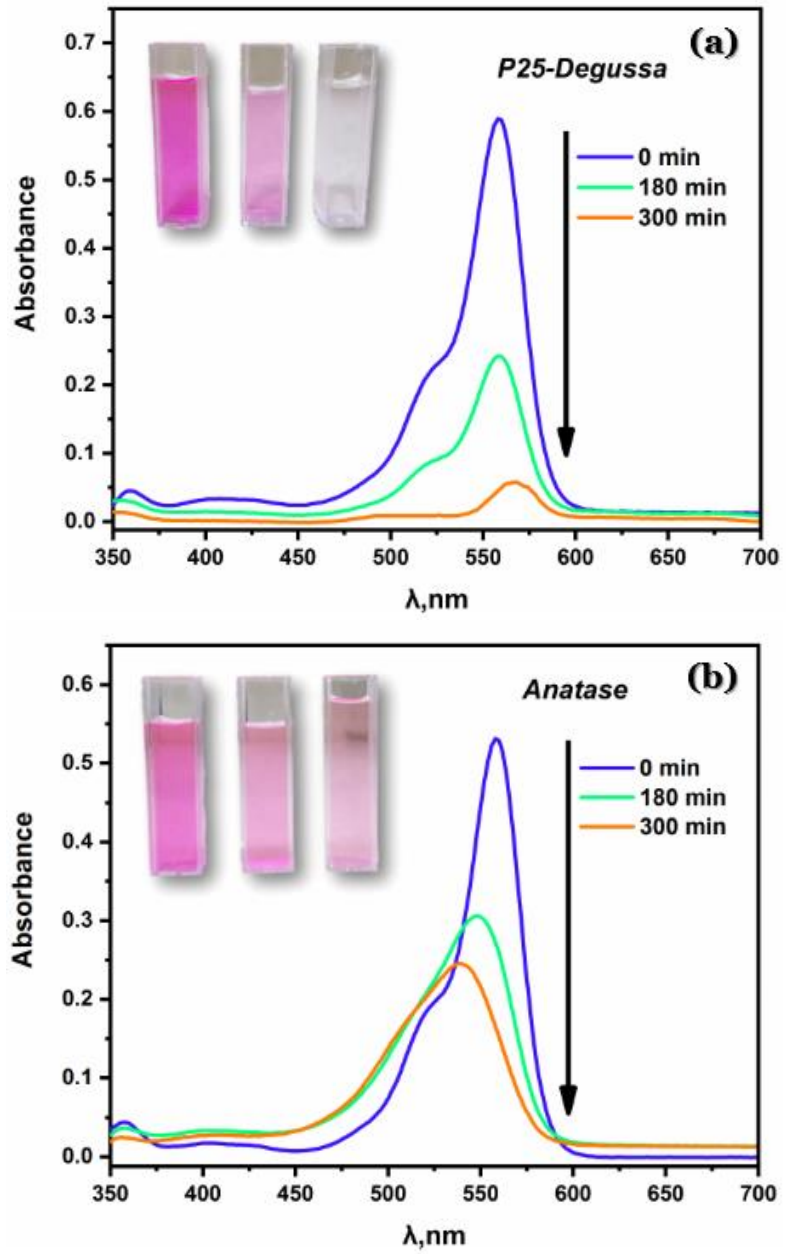

Fig. 7. Spectra of Rhodamine B samples degraded for 0 , 180 and 300 min using (a) P25 and (b) anatase photocatalysts. markedly to shorter wavelength (Fig. 7b). In the case of the P25 catalyst, spectra of the samples are slightly shifted to longer wavelengths (Fig. 7a). Probable mechanism of $\mathrm{RhB}$ photodegradation comprises three stages $[6,57]$. At first, auxochrome ethyl groups are detached from amino groups. Second, the deethylated products lose carboxyle group. Third stage is decomposition of chromophore core and formation of low molecular acidic compounds. Finally, carbon dioxide and water are formed.

The comparison of photocatalytic micro-reactors aimed to degradation of dyes are presented in Table 4. The advantages of the presented micro-reactor are low operating costs, simple experimental design, high energy efficiency and very narrow emission spectrum.

\section{Conclusions}

LED photocatalytic reactors can be successfully used to study degradation of organic pollutants. The important features of the LED UV sources are the following: (i) high energy efficiency; (ii) small size and low toxicity (Hg-free); (iii) high durability leading to long service life; (iv) very narrow emission spectrum. This paper presents new LED micro-photoreactor. The LED source is optimized for photocatalytic degradation of $\mathrm{RhB}$ dye. The main advantages of this microphotoreactor are: (i) low cost; (ii) low amount of photocatalyst used; (iii) rapid replacement of the light source to adjust wavelength range to absorption spectrum of model compound. The commercial LEDs with different characteristics (wavelength, radiation power) are widely available. The proposed microreactor may be used to select optimal reaction conditions, to evaluate efficiency of photocatalytic degradation and reactor energy consumption. Further development of such microreactors requires implementation of automatic systems to control light source when the sample reaches the desired percentage of degradation. In situ measurement can be used to monitor degradation of pollutants.

Table 4

Comparison of photocatalytic micro-reactors aimed to dye degradation

\begin{tabular}{|l|c|c|c|}
\hline \multicolumn{1}{|c|}{ Contaminant } & $\lambda_{\max }, \mathrm{nm}$ & $\lambda_{\text {LED }}, \mathrm{nm}$ & ref. \\
\hline Congo red & 500 & 365 & {$[59]$} \\
\hline Methyl orange & 464 & UV light & {$[60]$} \\
\hline Direct red 23 & 500 & 365 & {$[61]$} \\
\hline Reactive Red 120 & 522 & $315-400$ & {$[62]$} \\
\hline Reactive Red 231 & 545 & & \\
\cline { 1 - 2 } Reactive Orange 13 & 487 & 385 & {$[35]$} \\
\hline Reactive Black 5 & 598 & & {$[63]$} \\
\hline Reactive Blue 198 & 624 & UV light & {$[34]$} \\
\hline Direct red 80 & 528 & 370 & this work \\
\hline Methylene blue & 655 & 365 & \\
\hline Rhodamine B & 558 & &
\end{tabular}




\section{Acknowledgements}

ND and TT thank the Ministry of Education and Science of Ukraine for financial support in the framework of Ukrainian-Polish bilateral project "Photocatalytic hybrid systems for water purification". OS thanks the Ministry of Education and Science of Ukraine for financial support in the framework of project $0120 U 102035$.
Danyliuk N. - BSc, leading specialist at the Educational and Scientific Center of Material Science and Nanotechnology;

Tatarchuk T. - PhD in Chemistry, Associate Professor of the Chemistry Department, Director of Educational and Scientific Center of Material Science and Nanotechnology;

Shyichuk A. - Doctor of Chemical Sciences, Professor of the Chemistry Department.

[1] I. Anastopoulos, I. Pashalidis, A.G. Orfanos, I.D. Manariotis, T. Tatarchuk, L. Sellaoui, A. Bonilla-Petriciolet, A. Mittal, A. Núñez-Delgado, J. Environ. $\quad$ Manage. $261 \quad$ (2020) (https://doi.org/10.1016/j.jenvman.2020.110236).

[2] M. Naushad, A.A. Alqadami, A.A. Al-Kahtani, T. Ahamad, M.R. Awual, T. Tatarchuk, J. Mol. Liq. 296. 112075 (2019) (https://doi.org/10.1016/J.MOLLIQ.2019.112075).

[3] T. Tatarchuk, A. Shyichuk, I. Mironyuk, M. Naushad, J. Mol. Liq. 293, 111563 (2019) (https://doi.org/10.1016/j.molliq.2019.111563).

[4] M. Naushad, Z.A. ALOthman, Desalin. Water Treat. 53, 2158 (https://doi.org/10.1080/19443994.2013.862744).

[5] N. Phutanon, P. Pisitsak, H. Manuspiya, S. Ummartyotin, J. Sci. Adv. Mater. Devices. 3, 310 (2018) (https://doi.org/10.1016/j.jsamd.2018.05.001).

[6] N. Guo, H. Liu, Y. Fu, J. Hu, Optik (Stuttg) 201, 163537 (2019) (https://doi.org/10.1016/j.ijleo.2019.163537).

[7] Y. Wang, Q. Yang, X. Wang, J. Yang, Y. Dai, Y. He, W. Chen, W. Zhang, Mater. Sci. Eng. B Solid-State Mater. Adv. Technol. 244, 12 (2019) (https://doi.org/10.1016/j.mseb.2019.04.005).

[8] M.A. Lazar, S. Varghese, S.S. Nair, Catalysts 2, 572 (2012) (https://doi.org/10.3390/catal2040572).

[9] K. Karthik, S. Vijayalakshmi, A. Phuruangrat, V. Revathi, U. Verma, J. Clust. Sci. 30 (2019) (https://doi.org/10.1007/s10876-019-01556-1).

[10] R. Aswini, S. Murugesan, K. Kannan, Int. J. Environ. Anal. Chem. 00 (2020) (https://doi.org/10.1080/03067319.2020.1718668).

[11] V. Vaiano, M. Matarangolo, O. Sacco, Chem. Eng. J. 350, $703 \quad$ (2018) (https://doi.org/10.1016/j.cej.2018.06.011).

[12] S. Sa-nguanprang, A. Phuruangrat, K. Karthik, S. Thongtem, T. Thongtem, J. Aust. Ceram. Soc. (2020) (https://doi.org/10.1007/s41779-019-00447-y).

[13] V. Etacheri, C. Di Valentin, J. Schneider, D. Bahnemann, S.C. Pillai, J. Photochem. Photobiol. C Photochem. Rev. 25, 1 (2015) (https://doi.org/10.1016/j.jphotochemrev.2015.08.003).

[14] M. Buchalska, M. Kobielusz, A. Matuszek, M. Pacia, S. Wojtyła, W. Macyk, ACS Catal. 5, 7424 (2015) (https://doi.org/10.1021/acscatal.5b01562).

[15] S. Zhang, C.Y. Liu, Y. Liu, Z.Y. Zhang, L.J. Mao, Mater. Lett. $63, \quad 127$ (2009) (https://doi.org/10.1016/j.matlet.2008.09.032).

[16] L. Li, J. Yan, T. Wang, Z.J. Zhao, J. Zhang, J. Gong, N. Guan, Nat. Commun. 6, 1 (2015) (https://doi.org/10.1038/ncomms6881).

[17] J. Kang, L. Gao, M. Zhang, J. Pu, L. He, R. Ruan, M. Omran, J. Peng, G. Chen, Adv. Powder Technol. 6 (2020) (https://doi.org/10.1016/j.apt.2019.12.042).

[18] M. Nag, P. Basak, S.V. Manorama, Mater. Res. Bull. 42, 1691 (2007) (https://doi.org/10.1016/j.materresbull.2006.11.032).

[19] G. Nabi, Qurat-ul-Aain, N.R. Khalid, M.B. Tahir, M. Rafique, M. Rizwan, S. Hussain, T. Iqbal, A. Majid, J. Inorg. Organomet. Polym. Mater. 28, 1552 (2018) (https://doi.org/10.1007/s10904-018-0812-0).

[20] M. Surówka, M. Kobielusz, M. Trochowski, M. Buchalska, K. Kruczała, P. Broś, W. Macyk, Appl. Catal. B Environ. 247, 173 (2019) (https://doi.org/10.1016/j.apcatb.2019.01.074).

[21] I. Mironyuk, T. Tatarchuk, H. Vasylyeva, M. Naushad, I. Mykytyn, J. Environ. Chem. Eng. 7, 103430 (2019) (https://doi.org/10.1016/j.jece.2019.103430).

[22] I. Mironyuk, T. Tatarchuk, H. Vasylyeva, V.M. Gun'ko, I. Mykytyn, J. Mol. Liq. 282, 587 (2019) (https://doi.org/10.1016/j.molliq.2019.03.026).

[23] I. Mironyuk, T. Tatarchuk, M. Naushad, H. Vasylyeva, I. Mykytyn, J. Mol. Liq. 285, 742 (2019) (https://doi.org/10.1016/j.molliq.2019.04.111).

[24] A. Radoń, S. Łoński, T. Warski, R. Babilas, T. Tański, M. Dudziak, D. Łukowiec, Appl. Surf. Sci. 487, 1018 (2019) (https://doi.org/10.1016/j.apsusc.2019.05.091).

[25] J.C. Espíndola, V.J.P. Vilar, Chem. Eng. J. 394, 124865 (2020) (https://doi.org/10.1016/j.cej.2020.124865).

[26] M.H. Rasoulifard, M. Fazli, M.R. Eskandarian, J. Ind. Eng. Chem. 24, 121 (2015) (https://doi.org/10.1016/j.jiec.2014.09.018).

[27] N. Danyliuk, J. Tomaszewska, T. Tatarchuk, J. Mol. Liq. 309 , (2020). (https://doi.org/10.1016/j.molliq.2020.113077). 
[28] K. Karthik, V. Revathi, T. Tatarchuk, Mol. Cryst. Liq. Cryst. 671 , $17 \quad$ (2018) (https://doi.org/10.1080/15421406.2018.1542080).

[29] M. Naushad, A.A. Alqadami, Z.A. AlOthman, I.H. Alsohaimi, M.S. Algamdi, A.M. Aldawsari, J. Mol. Liq. 293, 111442 (2019) (https://doi.org/10.1016/j.molliq.2019.111442).

[30] T. Varadavenkatesan, E. Lyubchik, S. Pai, A. Pugazhendhi, R. Vinayagam, R. Selvaraj, J. Photochem. Photobiol. B Biol. 199, 111621 (2019) (https://doi.org/10.1016/j.jphotobiol.2019.111621).

[31] T.B. Wermuth, S. Arcaro, J. Venturini, T.M. Hubert Ribeiro, A. de Assis Lawisch Rodriguez, E.L. Machado, T. Franco de Oliveira, S.E. Franco de Oliveira, M.N. Baibich, C.P. Bergmann, Ceram. Int. 45, 24137 (2019) (https://doi.org/10.1016/j.ceramint.2019.08.122).

[32] K. Zhang, Z. Meng, W. Oh, Cuihua Xuebao/Chinese J. Catal. 31, 751 (2010) (https://doi.org/10.1016/S18722067(09)60084-X).

[33] S. Dominguez, M.J. Rivero, P. Gomez, R. Ibañez, I. Ortiz, J. Ind. Eng. Chem. 37, 237 (2016) (https://doi.org/10.1016/j.jiec.2016.03.031).

[34] L. Bukman, C.F. de Freitas, W. Caetano, N.R.C. Fernandes, N. Hioka, V.R. Batistela, Spectrochim. Acta - Part A Mol. Biomol. Spectrosc. 211, 330 (2019) (https://doi.org/10.1016/j.saa.2018.12.033).

[35] T. Tapia-Tlatelpa, J. Trull, L. Romeral, 9, 1 (2019) (https://doi.org/10.3390/catal9080669).

[36] J. Fernández-Catalá, G. Garrigós-Pastor, Berenguer-Murcia, D. Cazorla-Amorós, J. Environ. Chem. Eng. 7, 103408 (2019) (https://doi.org/10.1016/j.jece.2019.103408).

[37] Sutisna, M. Rokhmat, E. Wibowo, Khairurrijal, M. Abdullah, Sustain. Environ. Res. 27, 172 (2017) (https://doi.org/10.1016/j.serj.2017.04.002).

[38] V.J.P. Vilar, P. Alfonso-Muniozguren, J.P. Monteiro, J. Lee, S.M. Miranda, R.A.R. Boaventura, Chem. Eng. J. 379, 122341 (2020) (https://doi.org/10.1016/j.cej.2019.122341).

[39] D. Heggo, S. Ookawara, Chem. Eng. Sci. 16967 (2017) (https://doi.org/10.1016/j.ces.2017.01.019).

[40] K.P. Sundar, S. Kanmani, Chem. Eng. Res. Des. 154, 135

(2020) (https://doi.org/10.1016/j.cherd.2019.11.035).

[41] S.A. Joven-Quintero, S.F. Castilla-Acevedo, L.A. Betancourt-Buitrago, R. Acosta-Herazo, F. MachucaMartinez, Mater. Sci. Semicond. Process. 110, (2020) (https://doi.org/10.1016/j.mssp.2020.104972).

[42] S. Moeini Najafabadi, F. Rashidi, M. rezaei, Chem. Eng. Process. - Process Intensif. 146, 107668 (2019) (https://doi.org/10.1016/j.cep.2019.107668).

[43] A. Jamali, R. Vanraes, P. Hanselaer, T. Van Gerven, Chem. Eng. Process. Process Intensif. 71, 43 (2013) (https://doi.org/10.1016/j.cep.2013.03.010).

[44] B.M. da Costa Filho, A.L.P. Araujo, S.P. Padrão, R.A.R. Boaventura, M.M. Dias, J.C.B. Lopes, V.J.P. Vilar, Chem. Eng. J. 366, 560 (2019) (https://doi.org/10.1016/j.cej.2019.02.122).

[45] B. Tahir, M. Tahir, N.S. Amin, Energy Convers. Manag. 90, $272 \quad$ (2015) (https://doi.org/10.1016/j.enconman.2014.11.018).

[46] M. Jafarikojour, B. Dabir, M. Sohrabi, S.J. Royaee, J. Photochem. Photobiol. A Chem. 364,613 (2018) (https://doi.org/10.1016/j.jphotochem.2018.03.043).

[47] R. Oblak, M. Kete, U.L. Štangar, M. Tasbihi, J. Water Process Eng. 23, 142 (2018) (https://doi.org/10.1016/j.jwpe.2018.03.015).

[48] M. Khademalrasool, M. Farbod, M.D. Talebzadeh, J. Sci. Adv. Mater. Devices. 1, 382 (2016) (https://doi.org/10.1016/j.jsamd.2016.06.012).

[49] V. Vaiano, O. Sacco, G. Di Capua, N. Femia, D. Sannino, Water (Switzerland). 11, (2019) (https://doi.org/10.3390/w11081642).

[50] Z. Wang, J. Liu, Y. Dai, W. Dong, S. Zhang, J. Chen, Ind. Eng. Chem. Res. 50, 7977 (2011) (https://doi.org/10.1021/ie200297x).

[51] A. Phuruangrat, P.O. Keereesaensuk, K. Karthik, P. Dumrongrojthanath, N. Ekthammathat, S. Thongtem, T. Thongtem, J. Inorg. Organomet. Polym. Mater. 30 (2020) (https://doi.org/10.1007/s10904-019-01190-4).

[52] P. Intaphong, A. Phuruangrat, K. Karthik, T. Thongtem, S. Thongtem, Dig. J. Nanomater. Biostructures. 14 (2019).

[53] P. Intaphong, A. Phuruangrat, K. Karthik, P. Dumrongrojthanath, T. Thongtem, S. Thongtem, J. Inorg. Organomet. Polym. Mater. 30 (2020) (https://doi.org/10.1007/s10904-019-01259-0).

[54] R. Jain, M. Mathur, S. Sikarwar, A. Mittal, J. Environ. Manage. 85, 956 (2007) (https://doi.org/10.1016/j.jenvman.2006.11.002).

[55] J. Duraimurugan, S.K. G., S. Shanavas, R. Ramesh, R. Acevedo, P.M. Anbarasan, P. Maadeswaran, Optik (Stuttg) 202, 163607 (2020) (https://doi.org/10.1016/j.ijleo.2019.163607).

[56] R. Hao, G. Wang, C. Jiang, H. Tang, Q. Xu, Appl. Surf. Sci. 411, 400 (2017) (https://doi.org/10.1016/j.apsusc.2017.03.197).

[57] D.C. Khandekar, A.R. Bhattacharyya, R. Bandyopadhyaya, J. Environ. Chem. Eng. 7, 103433 (2019) (https://doi.org/10.1016/j.jece.2019.103433).

[58] C. Casado, R. Timmers, A. Sergejevs, C.T. Clarke, D.W.E. Allsopp, C.R. Bowen, R. van Grieken, J. Marugán, Chem. Eng. J. 327, 1043 (2017) (https://doi.org/10.1016/j.cej.2017.06.167). 
[59] J. Fowsiya, G. Madhumitha, N.A. Al-Dhabi, M.V. Arasu, J. Photochem. Photobiol. B Biol. 162, 395 (2016) (https://doi.org/10.1016/j.jphotobiol.2016.07.011).

[60] X. Zheng, D. Zhang, Y. Gao, Y. Wu, Q. Liu, X. Zhu, Inorg. Chem. Commun. 110, 107589 (2019) (https://doi.org/10.1016/j.inoche.2019.107589).

[61] M. Torkaman, R. Moradi, B. Keyvani, Rev. Roum. Chim. 61, 763 (2016).

[62] Y.P. Ong, L.N. Ho, S.A. Ong, J. Banjuraizah, A.H. Ibrahim, S.L. Lee, N. Nordin, Chemosphere 219, 277 (2019) (https://doi.org/10.1016/j.chemosphere.2018.12.004).

[63] M. Nawaz, W. Miran, J. Jang, D.S. Lee, Catal. Today 282, 38 (2017) (https://doi.org/10.1016/j.cattod.2016.02.017).

\author{
Н.В. Данилюк, Т.Р. Татарчук, О.В. Шийчук
}

\title{
Мікрореактор періодичної дії для моніторингу фотокаталітичних реакцій
}

ДВНЗ «Прикарпатський національний університет імені Василя Стефаника», Івано-Франківськ, Украӥна, danyliuk.nazariy@gmail.com

\begin{abstract}
Фотокаталітичне окислення органічних забруднень $є$ актуальною темою екологічних досліджень. Однак для ефективного процесу очищення потрібен ефективний фотореактор. При цьому типові джерела світла, такі як ртутна та галогенні лампи, повинні бути замінені на енергоефективні світлодіоди. У цій роботі представлено мініатюрний фотореактор, який для досліджень потребує малу кількість фотокаталізатора. Робота мікрофотореактора досліджувалася 3 використанням анатазу та титан (IV) оксиду (Р25), як модельних фотокаталізаторів, та родаміну В, як модельного забруднювача. Ключовим елементом мікрореактора $є$ змінний УФ-світлодіод. Довжина хвилі його випромінювання становить 365 нм і $є$ оптимальною для модельного забруднювача барвника родаміну Б. Представлений мікрореактор здатний майже повністю мінералізувати забруднюючий барвник і його можна використовувати для різних фотокаталітичних досліджень
\end{abstract}

Ключові слова: мікрофотореактор, родамін В, фотокаталізатор, світлодіод, фотодеградація. 